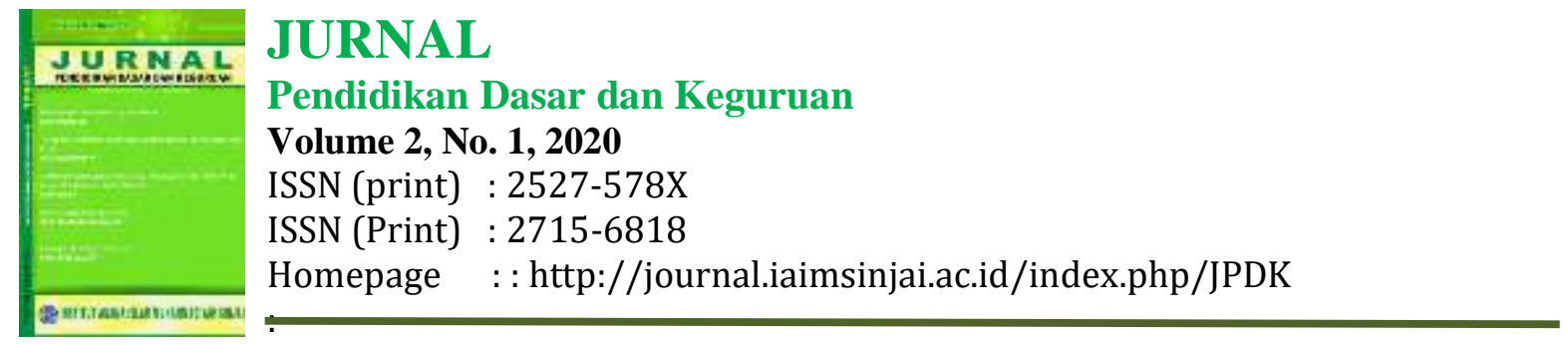

\title{
KOPETENSI PEDAGOGIK GURU DALAM MENDESAIN PEMBELAJARAN DI SD NEGERI 23 TOLITOLI
}

\author{
Sitti Nuralan ${ }^{1}$ \\ ${ }^{1}$ Universitas Madako Tolitoli, Tolitoli, Gorontalo, Indonesia \\ sitticuteaisyah@gmail.com
}

\begin{abstract}
Abstrak
Artikel ini bertujuan untuk mengetahui bagaimana kondisi kemampuan kompetensi pedagik guru dalam mendesain pembelajaran di SD Negeri 23 Tolitoli. Penelitian ini menggunakan deskriftif kualitatif, yaitu penelitian yang dilakukan dengan menguumpulkan data-data serta dinyatakan dalam bentuk kata-kata dan gambar, dimana kata-kata disusun dengan kalimat misalkan hasil wawancara antara peneliti dengan informan. Metode pengumpulan data menggunakan observasi, wawancara, dan dokumentasi. Metode analisis data menggnakan tiga cara yaitu reduksi data, display data dan verivikasi atau penarikan kesimpulan. Kesimpulan pada artikel ini yaitu Guru di SD Negeri 23 Tolitoli memiliki kompetensi yang cukup baik dalam mendesain pembelajaran, meskipun ada beberapa komponen yang belum terlaksana sepennhnya
\end{abstract}

Kata Kunci: Kompetensi, Pedagogik, Guru, Desain Pembelajaran.

\begin{abstract}
Abstrack
This article aims to find out the condition of the teacher's pedagic competence in designing learning in Tolitoli 23 Public Elementary School. This study uses qualitative descriptive, namely research conducted by collecting data and expressed in the form of words and images, where words are arranged in sentences for example the results of interviews between researchers and informants. Data collection methods use observation, interviews, and documentation. The data analysis method uses three ways, namely data reduction, data display and verification or conclusion drawing. The conclusion of this article is that the teacher at Tolitoli 23 Public Elementary School has a fairly good competency in designing learning, even though there are some components that have not been implemented properly.
\end{abstract}

Keyword: Competence, Pedagogic, Teacher, Learning Design. 


\section{Pendahuluan}

Kemampuan pedagogic ialah kemampuan utama seorang guru dalam melakukan suatu proses pembelajaran secara maksimal dengan menggunakan berbagai metode dan model pembelajaran, dimana hal tersebut sering dianggap sepeleh oleh seorang guru. Kemampuan pedagogic yang dimiliki seorang guru dapat secara maksimal membantu perkembangan seoranf siswa. Saat merancang sebuah pembelajaran, guru diharapkan mampu untuk merancang suatu kegiatan pembelajaran yaitu merumuskan tujuan, memilih bahan, memilihh metode dan menetapkan evaluasi.

Kemampuan pedagogic seorang guru mengharuskan guru untuk mempersiapakan berbagai pembelajaran sebelum mengajar. Oleh karna itu seorang guru harus menguasai berbagai komponen mendesain pembelajaran dan menerapkannya dikelas. Hal tersebut menjadi integral dan menjadi satu kesulitan yang saling memiliki keterkaitan antara satu dengan lainnya, sehingga harus dipenuhi dalam suatu proses pembelajaran atau belajar mengajar. Bagian-bagian ini saling terintegrasi sebagai suatu satu kesatuan yang dipersiapkandan dirancang oleh seorang gurusebelum memulain suatu proses pembelajaran atau belajar mengajar dikelas dalam bentuk rencana pelaksannaan pembelajaran (RPP) sebagai salah satu desain suatu pembelajaran.

Dari hasil observasi yang dilakkan peneliti pada tanggal 17 Maret 2019 di SD Negeri 23 Tolitoli, bahwa semua guru yang mengajar disana mmemiliki kemampuan pedagogic yang cukup baik, namun masih ada beberapa bagian dalam proses pembelajaran yang belum terpenuhi dengan maksimal seperti ketika guru merancang pembelajran, tujuan pembelajran masih ada yang belum tercapai sesuai dalam mendesai pembelajaran dan masih kurang dalam mempertimbangkkan karakteristik peserta didik. Seperti yang diketahui kemampuan pedagogic merupakan suatu kemampuan dalam mengelolah pembelajaran dikelas. Pada suatu situasi pembelajaran tentunya seorang guru harus mempersiapkan atau mendesain pembelajaran terlebih dahulu sebelum kegiatan kegiatan berlangsung.

Berdasarkan uraian masalah diatas peneliti tertarik untuk meneliti mengenai kemampuan pedagogic guru dalam mendeesain suatu pembelajaran ddi SD Negeri 23 Tolitoli " salah satu alas an peneliti mengangkat judul ini, karna seringnya terdapat permasalahan mengenai kemampuan pedagogic seorang guru yang memberikan dampak yang signifikan bagi para guru dalam mendesain pembelajaran.

Peraturan Pemerintah Republik Indonesia Nomor 19 Tahan 2005 tentang Standar Nasional pendidikan, menjelaskan bahwa kompetensi pedagogik adalah kemampuan pengelolaan pembelajaran peserta didik yang meliputi pemahaman terhadap peserta didik, perancangan, pelaksanaan pembelajaran, evaluasi hasil belajar, dan pengembangan peserta didik untnk mengaktualisasikan berbagai potensi yang dimilikinya.

Kemapuan Pedagogik menurut J. Hoogveld (Belanda) pedagogic adalah "Ilmu yang mempelajari masalah membimbing anak kearah tujuan tertenu, yaitu supaya kelak iya bisa secara mandiri menyelesaikan tugas hidupnya". Sedangkan Menurut suarno "Pedagogik iayalah pendidikan, yang lebih menekankan pada praktek, yang menyangkut pada kegiatan mendidik, kegiatan membimbing anak, pedagogic merupakan suatu teori yang secara teliti, kritis dan objektif mengembangkan konsep-konsep mengenai hakikat manusia, hakikat anak, hakikat tujuan suatu pendidikan serta proses pendidikan.

Salah satu kompetensi yang harus dimiliki seorang pendidik ialah kompetensi pedagogik, kompetensi pedagogik bukan hanya bagaimana dari guru mengelolah pembelajaran melainkan berkenaan dengan ilmu mendidik, membimbing serta mengantar peserta didik menjadi pribadi yang dewasa yang mampu menyelesaikan tugas hidapnya secara mandiri.

Kompenen-Komponen kompetensi Pedagogik terdiri atas 3 yaitu:

\subsection{Mengenal karakteristiik Peserta Didik}

Berdasarkan Peraturan Menteri pendidikan (Kemendiknas) salah satu komptensin pedagogik yang harus dimiliki,dikuasai serta dilaksanakan oleh seorang guru sebagai upaya untuk mengujudkan suatu kinerja yang efektif dan optimal yaitu dengan menguasai karakteristik peserta didik. 


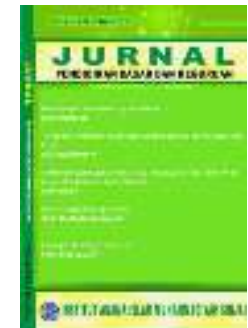

JURNAL

Pendidikan Dasar dan Keguruan

Volume 2, No. 1, 2020

ISSN (print) : 2527-578X

ISSN (Print) : 2715-6818

Homepage : : http://journal.iaimsinjai.ac.id/index.php/JPDK

Karakteristik peserta didik adalah salah satu variabel dari suatu kondisi pengajaran, variabel didefinisikan sebagai aspek-aspek kualitas perorangan, dimana aspek ini berupa bakat, minat, sikap, motivasi belajar, gaya belajar, kemampuan berfikir serta kernampuan awal yang dimilikinya. Seorang guru dapat merencanakan merencanakan serta melaksanakan pembelajaran dengan menggunakan strategi, metode serta bahan pembelajaran yang efektif dan efisienyang sesuai dengan karakteristik peserta didik.

\subsection{Pengembangan Kurikulum}

Peranan penting kurikulum dalam sistem pendidikan bukan hanya merumuskan tentang tujuan yang harus dicapai sehingga memperjelas arah pendidikan akan tetapi juga memberikan pemahaman tentang suatu pengalaman belajar yang harus dimikili oleh seorang siswa. Indikator dan Aspek Pedagogik yaitu: Menguasai dan memahami karakteristik peserta didik, Pengamatan kurikulum, Pelaksanaan Kegiatan yang mendidik

Faktor yang mempengaruhi kopetensi pedagogic Guru pada proses penyelenggaraan pendidikan disekolah kompetensi, kepala sekolah, kesiapan samoa prasarana" ketersediaan dana" dan program yang telah direncanakan, adalah faktor-faktor yang turut berperan dalam meningkatkan produktivitas lembaga pendidikan di sekolah tersebut. Akan tetapi faktor yang paling esensial dalam proses pendidikan adalah manusia yang memiliki tugas dengan pekerjaan yang menghasilkan perubahan yang direncanakan pada pada anak didik..

\subsection{Rencana Pelaksanaan Pembelajaran}

Secara terminology. Kata perencanaan pembelajaran terdiri dari dua kata yaitu perencanaan dan kata pembelajaran. Perencanaan berasal dari kata rencana ialah mengambil suatu keputusan tentan apa yang harus dilakukan untuk mencapai suatu tujuan. Sehingga suatu proses perencanaan haruslah dimulai dari suatu penetapan tujuan yang akkan dicapai melalui analisis kebutuhan serta dokumen yang lengkap, selanjutnya menettapkan langkah-langkah yang harus dilakukan untuk mencapai tujuan ttersebut.

Sedangan kata pembelajaran adalah prosses keerjasama antara siswa dengan guruuntuk memamfaatkan segala potensi dengan sumber yang ada baik potensi yang bersumber dari dalam diri siswa itu sendiri yaitu minat, bakat, dan kemampuann dasar yang dimiliki siswa termasuk gaya belajar atauupun potensi yang berasal dari luar dirinya, seperti lingkungan, sarana dan sumber belajar sebagai upaya untuk mencapai sebuah tujuan yang ingin dicapai atau direncanakan.

Dari kedua pengertian diatas ,dapat disimppulkan bahwa perencanaan dan pembelajaran dapat disimpulkan merupakan proses pengambilan keputuusan hasil berfikir yang rasiional tentang sasaran dan tujuan pembelajaran tertentu, yaitu perubahan tingkalaku serta rangkaian kegiatan ang harus dilaksanakan sebagai upaya pencapaian suatu tujuan dengan memamfaatkan potensi dan sumber belajar yang ada.

\subsection{Mendesai Pembelajaran}

Sagala (2005) desain pembelajaran adalah pengembangan pembelajaran yang sistematik yang digunakan secara khusus teori-teori pembelajaran untuk menjamin kualitas pembelajaran. Gentry (198.5) desain pembelajaran merupakan proses menentukan proses tujuan pembelajaran , strategi dann tehnik untuk mencapai tujuan serta merancang media yang digunakan untuk keefektifan pencapaian tujuan

\section{Metode}

Penelitian ini adalah penelitian deskriftif kualitatif, yaitu penelitian yang dilakukan dengan menguumpulkan data-data serta dinyatakan dalam bentuk kata-kata dan gambar, dimana kata-kata disusun dengan kalimat misalkan hasil wawancara antara peneliti dengan informan.

Dalam penelitian ini menggunakan pendekatan kualitatif yaitu untuk mendapatkan informs yang sebenar-benarnya mengenai kopetensi pedagogic seorang guru dalam mendesain sebuuah pembelajaran di SD Negeri 23 Tolitoli. Waktu penelitian dilakukan dilakukan pada semester genap tahun ajaran 2018/2019 pada bulan Maret- Mei 2019 berlokasi di SD Negeri 23 Tolitoli. Subyek 
penelitian ini adalah tiga orang guru di SD Negeri 23 Tolitoli yang memfokuskan pada kompetesi pedagogic guru dalam mendesai sebuah pembelajaran.

Adapun tehnnik pengumpulan data yang dilakukan yaitu, tehnik observasi, wawancara yang terdiri dari wawancra terstruktur dan wawancara tidak terstrktur serta tehnik pengambilan dokumentasi. Pengukuran variable dalam penelitian ini menggunakan instrument pendukung yaitu wawancara serta pihak-pihak yang membantu dalam proses penelitian. Prosedur dalam penelitian ini yaitu tahap pra-lapangan, tahap lapangan,tahap analisis data : reduksi data, display dan verification.

\section{Hasil dan Pembahasan}

Tujuan pembelajaran itu harus dirancang sendiri oleh guru" hal ini dikarenakan ketika seorang guru tidak menyesuaikan atau merancang tujuan pembelajaran maka proses pembelajaran yang akan dilakukan tidak akan berjalan dengan tujuan yang ingin dicapai, dalam rnerancang atan membuat RPP tentu akan menentukan tujuan yang akan dicapai, Akan tetapi, sebelum itu terlebih dahulu seorang guru haruslah menentukan indoaktor-indikator dari kompetensi dasar yang sudah ada dalam komponen RPP tersebut, Apalagi di SD Negeri 23 Tolitoli telah menggunakan kurikulum 2013. Guru sebagai perancang pembelajaran haruslah menentukan pembelajaran yang harus dicapai yang tentunya harus menyesuaikan dengan aspek kognetif, afektif dan psikomotorik peseerta didik. Mengidentifikasi karakteristik peserta didik itu adalah kewajiban bagi seorang guru. Ha1 ini dikarenakan dengan guru mengetahui masing-masing keunikan yang dimiliki peserta didiknya tentu akan mudah rnenyesuaikan dalam proses belajar mengajar dikelas, Cara yang kita lakukan untnk mengenali peserta didik disini adalah dengan melakukan pendekatan pada masing-rnasing peserta didik tersebut tentunya bukan hanya dengan satu atau dua peserta didik akan tetapi, dengan semuanya dengan cara yang berbeda-beda pula. Seperti ketika peserta didik mengalami kesalitan dalam belajar tentu kita melakukan pendekatan dengan cara rnengajak "ngobrol" sehingga peserta didik tidak segan mengungkapkan keluhan yang dialaminya,

Berdasarkan basil analisis data dan pembahasan-pembahasan dapat ditarik kesimpulan bahwa hasil penelitian rnenunjukkan bahwa guru di SD Negeri 23 Tolitoli memiliki kompetensi yang cukup baik dalam mendesain pembelajaran, meskipun ada beberapa komponen yang belum terlaksana sepennhnya. Oleh karena itu, guru perlu mengembangkan kompetensi yang dimiliki agar dalam melaksanakan tugas keprofesionalnya sebagai pendidik semakin baik, Dengan demikian kompetensi guru dalam mendesain pembelajaran adalah satu kemampuan yang harus dimiliki dalam melaksanakan tugasnya sebagai guru profesional, Berdasarkan hasil penelitian yang dilakukan oleh peneliti menunjukkan bahwa

a. Desain pembelajaran yang disusun oleh guru-guru di SD Negeri 23 Tolitoli sudah sesuai dengan tujuan pembelajaran yang sudah direncanakaan dan dapat dilihat dari proses belajar yang baik dan hasil belajar siswa selama proses pembelajaran .

b. Desain pembelajaran yang dirancang sudah menyesuaikan dengan karakteristik peserta didik walaupun belum sepenuhnya maksimal.

\section{Daftar Pustaka}

Achsanuddin ..". (2011). Program Pengalaman Lapangan Wahana Pembentukan Profesional guru ", Yogyakarta; Kurnia Kalam semesta.

Ahmadi Rulam. (2014) "Uetodologi Penelitian Kualitatif" .Jakarta.Ar-Ruzz media.

Ariknnro Snharsimi. (2010.) Prosedur penelitian Suatu Pendekatan Praktik. Jakarta PT Rineka Cipta.

Uno B. Hamza, Perencanaan Pembelajaran, Jakarta: PT Bumi Aksara, 2006. Hanafiah Nanang, Konsep Strategi Pembelajaran, Bandung : Refika Aditama, 200 '9.

Hully dan Mukthar. (2012. Pro/est Keguruan. Yogyakarta: Alam Tara Institute. 


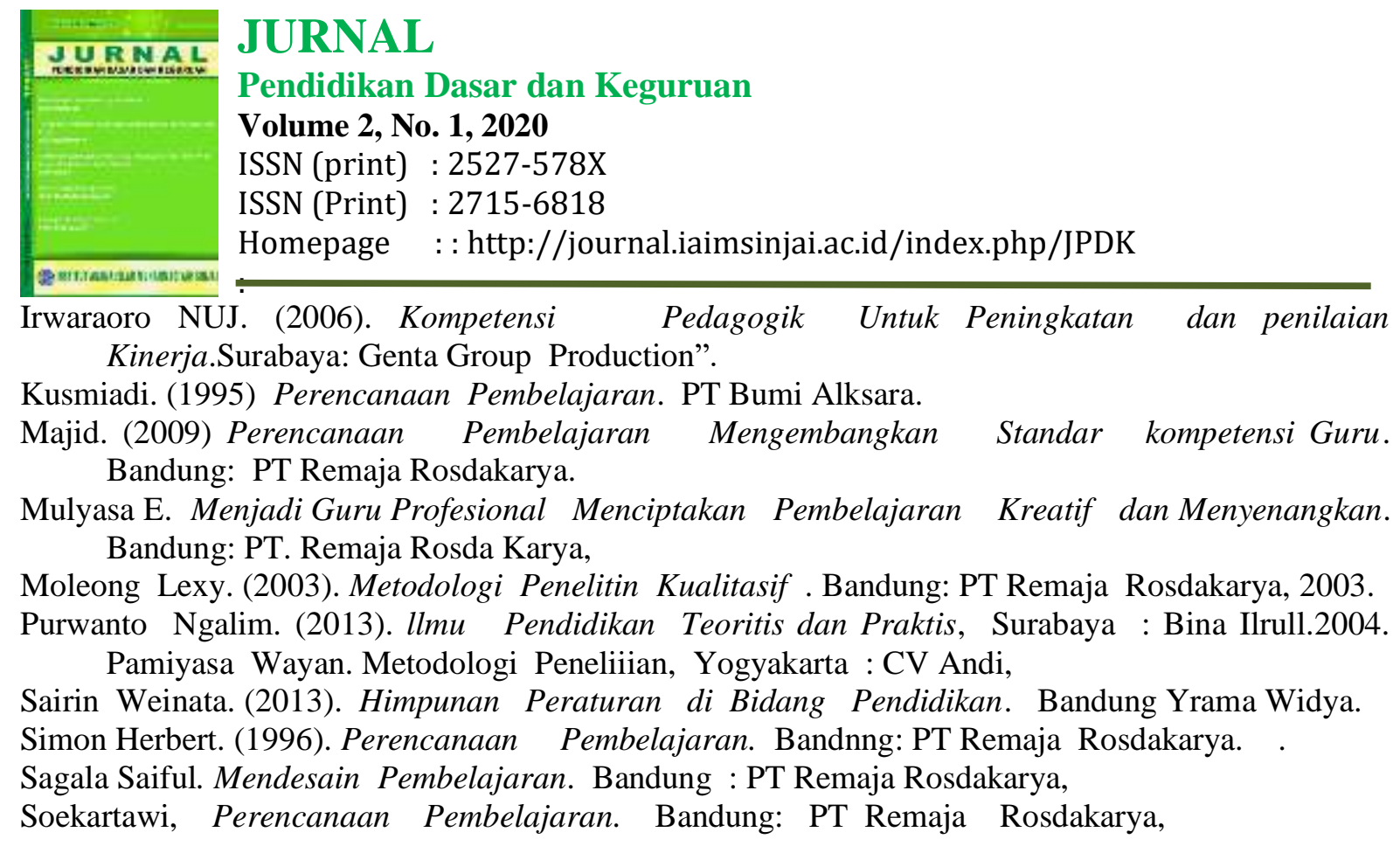

